Jurnal Terapan Teknik Mesin, Vol. 1, No. I, April 2020, 1 - 11

\title{
Perancangan Bentuk Penyaring Sampah Pada Alat Penyaring Sampah Sungai
}

\author{
Besse Titing Karmiati ${ }^{*}$, Ressy Noor Rafiq ${ }^{2}$ \\ 1 Teknik Mesin, Universitas Jenderal Achmad Yani \\ 2 Teknik Metalurgi, Universitas Jenderal Achmad Yani \\ *E-mail: Best_think09@ymail.com, ressynoorrrafiq@gmail.com
}

\begin{abstract}
Abstrak Sungai Cidurian terletak di kota. Bandung, Jawa Barat, adalah sungai yang membiakkan Sungai Citarum, tetapi sungai ini adalah salah satu sungai dengan tingkat pencemaran tertinggi, pencemaran sungai akibat sampah yang dibuang ke sungai oleh orang-orang yang tidak bertanggung jawab, hal ini dapat menyebabkan pendangkalan, sehingga berpotensi menyebabkan pendangkalan, sehingga berpotensi menyumbat aliran sungai. Akibatnya aliran sungai akan terhambat, jika sampai hujan sungai akan meluap dan menyebabkan banjir. Peningkatan teknologi penyaringan limbah sungai saat ini masih memiliki banyak masalah dan kendala, mulai dari banyaknya alat penyaringan limbah sungai yang masih membutuhkan daya dalam jumlah besar, hingga dimensi besar. Maka perlu dilakukan pengembangan dengan menganalisis beberapa bentuk filter untuk mendapatkan bentuk filter limbah sungai sesuai dengan karakter sungai. Merencanakan dan mengklarifikasi tugas-tugas merancang konsep produk, merancang bentuk produk (desain perwujudan). Penelitian ini adalah filter sampah berbentuk roda ferris roda 4 yang terbuat dari plat aluminium yang berputar searah jarum jam, masing-masing lengan memiliki kapasitas $7 \mathrm{~kg} /$ putaran dan kebutuhan daya filter adalah 151,62 Watt. Dengan kapasitas $7 \mathrm{~kg}$ / bulat dengan kebutuhan daya filter 151,62 Watt untuk membersihkan sampah.
\end{abstract}

Kata kunci: Limbah Sungai, Filter Limbah, Debit Air.

Abstract Cidurian River located in the city. Bandung, West Java, is a river that breeds the Citarum River, but this river is one of the highest polluting rivers, pollution of the river due to garbage dumped into the river by irresponsible people, this can cause siltation, so that it will potentially clog the river flow. Consequently the river flow will be obstructed, if it comes to rain the river will overflow and cause flooding. Improvement of river waste filtering technology currently still has many problems and constraints, ranging from the large number of river waste filtering tools that still require large amounts of power, up to large dimensions. Then it is necessary to do a development by analyzing some form of filter to get the form of river waste filter in accordance with the character of the river. Planning and clarifying the tasks designing the product concept, designing the product form (embodiment design). This research is a 4-arm ferris wheel-shaped trash filter made of aluminum plate which rotates clockwise, each arm has a capacity of $7 \mathrm{~kg} /$ round and the filter power requirement is 151.62 Watt. With a capacity of $7 \mathrm{~kg} /$ round with a filter power requirement of 151.62 Watts to clean waste.

Keywords: River Waste, Waste Filter, Water Discharge.

\section{PENDAHULUAN}

Sungai Cidurian yang berlokasi di kota. Bandung Jawa Barat ini adalah sungai yang menginduk ke sungai Citarum, namun sungai ini menjadi salah satu sungai yang tingkat ketercemaran tertinggi, tercemarnya sungai diakibatkan sampah yang dibuang ke sungai oleh

JTTM : Jurnal Terapan Teknik Mesin is licensed under a Creative Commons AttributionNonCommercial 4.0 International License.

Perancangan Bentuk Penyaring Sampah Pada Alat Penyaring Sampah Sungai - Besse Titing Karmiati, Ressy Noor Rafiq 
Jurnal Terapan Teknik Mesin, Vol. 1, No. I, April 2020, 1-11

masyarakat yang tidak bertanggung jawab hal ini dapat menimbulkan pendangkalan, sehingga akan berpotensi menyumbat aliran sungai, akibatnya aliran sungai akan terhambat, jika datang hujan sungai tersebut akan meluap dan menyebabkan bencana banjir [1].

Peningkatan teknologi penyaringan sampah sungai sekarang ini masih memiliki banyak masalah dan kendala, mulai dari banyaknya alat penyaringan sampah sungai yang masih memerlukan daya yang besar, sampai dimensi yang cukup besar [2]. Maka perlu dilakukan suatu pengembangan dengan menganalisa beberapa bentuk penyaring untuk mendapatkan bentuk penyaring sampah sungai yang sesuai dengan karakter sungai. Beberapa penelitian mengenai alat untuk menyaring sampah sudah pernah dilakukan diantaranya adalah "F-Filter (Fetch Filter), lengan penyaring sampah otomatis berbasis waktu sebagai pembersih sungai di daerah perkotaan" [1]."Kincir angin pengangkat sampah permukaan dan melayang memanfaatkan tenaga air, dengan satu kincir penggerak [3]". "Pengangkat sampah terapung dengan kincir [4] hidrolik ganda". Penelitian ini menggunakan alat multi purpose teaching flume sebagai simulasi aliran air dan tempat untuk menguji kincir pengangkat sampah tenaga air dengan dua kincir penggerak.

Hasil kajian mengenai prospek pemanfaatan penyaring sampah sungai dalam Implementasi imbal jasa lingkungan menjelaskan bahwa ada beberapa konsep teknologi pembersih sampah sungai, antara lain yang mobile dan yang static. Teknologi pembersih yang statik adalah konsep menempatkan alat pembersih pada suatu tempat yang menetap, antara lain alat [5]:

a) Pembersih sampah sungai dengan penggerak kincir memanfaatkan tenaga air dan alat.

b) Pembersih sampah sungai terintegrasi dengan sistem conveyor tenaga listrik.

Untuk mendapatkan hasil perancangan alat penyaring sampah dengan memanfaatkan aliran sungai sesuai karakteristik sungai Cidurian.

\section{METODE}

Prosedur perancangan mengacu pada metode Pahl dan Beits: Engineering Design: $A$ Systematic Approach yang terdiri dari 4 fase, keempat fase tersebut adalah:

1. Perencanaan.

2. Penjelasan tugas.

3. Perancangan konsep produk.

4. Perancangan bentuk produk (embodiment design).

2.1. Perancangan detail.

2.1.1. Perencanaan bentuk penyaring sampah sungai.

Observasi dilakukan di daerah sekitaran sungai Cidurian yang terletak di Kecamatan Rancasari kota Bandung. Sungai ini memiliki ruas kecil dengan panjang $20 \mathrm{~km}$. Dalam analisis keadaan sungai dilakukan survei di 4 titik sungai sehingga diperoleh data-data sebagai berikut:

JTTM : Jurnal Terapan Teknik Mesin is licensed under a Creative Commons AttributionNonCommercial 4.0 International License.

Perancangan Bentuk Penyaring Sampah Pada Alat Penyaring Sampah Sungai - Besse Titing Karmiati, Ressy Noor Rafiq 
Jurnal Terapan Teknik Mesin, Vol. 1, No. I, April 2020, 1 - 11

1. Lokasi survei.

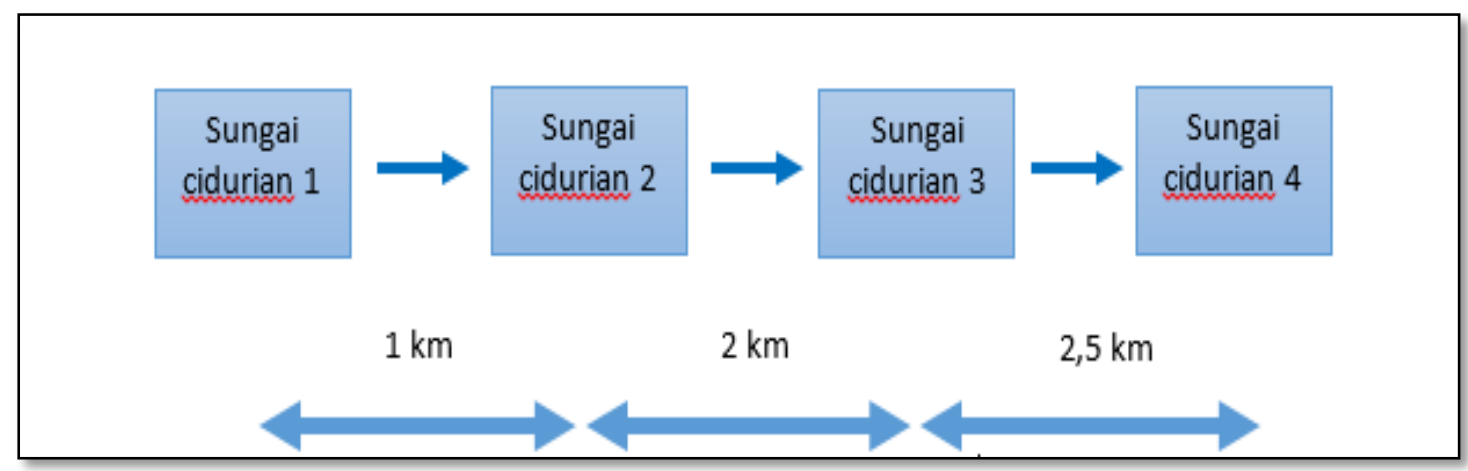

Gambar 1. Lokasi kegiatan survei.

Dipilih sungai Cidurian 3 dengan data berikut:
a. Lebar sungai
: $12 \mathrm{~m}$.
b. Ketinggian air sungai
$0.71 \mathrm{~m}$
c. Debit air sungai
: $2.685 \mathrm{~m}^{3} / \mathrm{s}$.

2.2 Pengelompokan kebutuhan

Berdasarkan hasil observasi dan analisa sungai, maka dikelompokan beberapa kebutuhan alat antara lain penggerak, penyaring sampah, membawa sampah ke pinggir sungai. Alat penyaring sampah memanfaatkan aliran sungai untuk penggerak, sehingga penggerak yang digunakan cocok untuk ketinggian rendah dan untuk debit sungai kecil, Dimensi alat yang diperlukan tidak terlalu besar, penyaring sampah sebaiknya ringan sehingga mudah digunakan dan dipindahkan. Perawatan juga sebaiknya mudah karena alat ini akan beroperasi selama 24 jam, serta faktor keamanan dan keselamatan sangat diperlukan dalam pengoperasian alat penyaring sampah tersebut.

2.3 Kriteria penyaring sampah sungai.

Tabel 1. Kriteria penyaring sampah sungai.

\begin{tabular}{lll}
\hline No & Kriteria Perbandingan & \multicolumn{1}{c}{ Persyaratan } \\
\hline \multirow{2}{*}{1} & Kinematika & Beban $7 \mathrm{Kg}$ \\
\cline { 3 - 3 } & & Mekanisme sederhana \\
\cline { 3 - 3 } 2 & Geometri & Panjang alat $1.2 \mathrm{~m}$ \\
\cline { 3 - 3 } & & Ringan \\
\hline
\end{tabular}

JTTM : Jurnal Terapan Teknik Mesin is licensed under a Creative Commons AttributionNonCommercial 4.0 International License.

Perancangan Bentuk Penyaring Sampah Pada Alat Penyaring Sampah Sungai - Besse Titing Karmiati, Ressy Noor Rafiq 
Jurnal Terapan Teknik Mesin, Vol. 1, No. I, April 2020,1-11

\begin{tabular}{lll}
\hline \multirow{2}{*}{3} & Material & Material ringan \\
\cline { 3 - 3 } & & Mutu baik \\
\hline 4 & Ergonomi & Tahan korosi \\
\hline 5 & Perawatan & Aman digunakan \\
\hline 6 & Produksi & Pemeliharaan mudah \\
\hline 7 & Keselamatan & Sidak perlu perawatan \\
\hline
\end{tabular}

2.4 Penyaringan sampah sungai

Penyaringan yang dibutuhkan adalah penyaring sampah yang digerakkan oleh daya yang kecil, sehingga penyaring sebaiknya ringan dan tidak terlalu besar. Dari penelitian sebelumnya diperoleh beberapa bentuk yang bisa dijadikan acuan dalam pembuatan dan pengembangan penyaring sampah ini. Bentuk penyaring sebelumnya antara lain:

1. Penyaring sampah yang berbentuk kincir pembawa sampah [3].

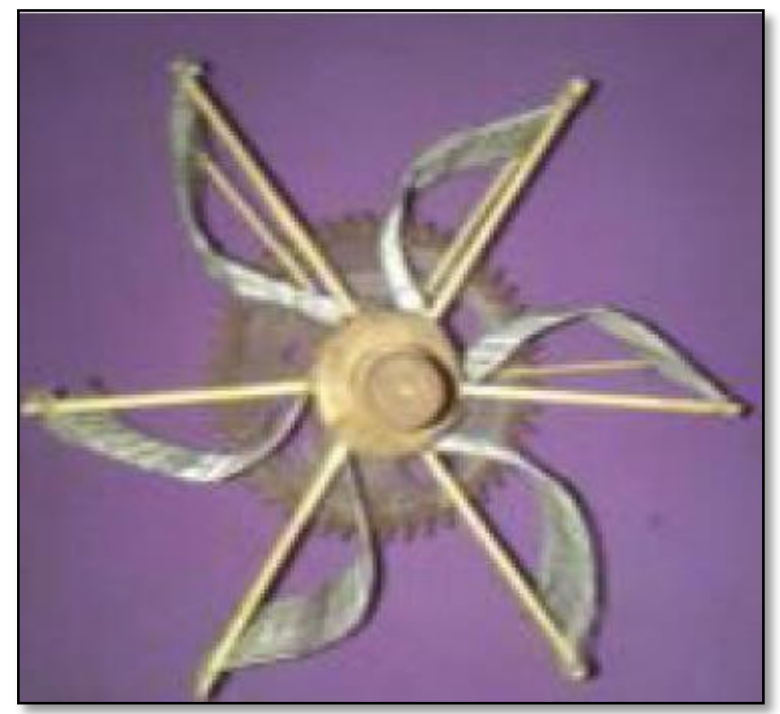

Gambar 2. Kincir pembawa sampah.

JTTM : Jurnal Terapan Teknik Mesin is licensed under a Creative Commons AttributionNonCommercial 4.0 International License.

Perancangan Bentuk Penyaring Sampah Pada Alat Penyaring Sampah Sungai - Besse Titing Karmiati, Ressy Noor Rafiq 


\section{$\overline{J T T M}$}

Jurnal Terapan Teknik Mesin, Vol. 1, No. I, April 2020,1-11

2. Penyaring sampah berbentuk bucket dengan 4 celah [6].

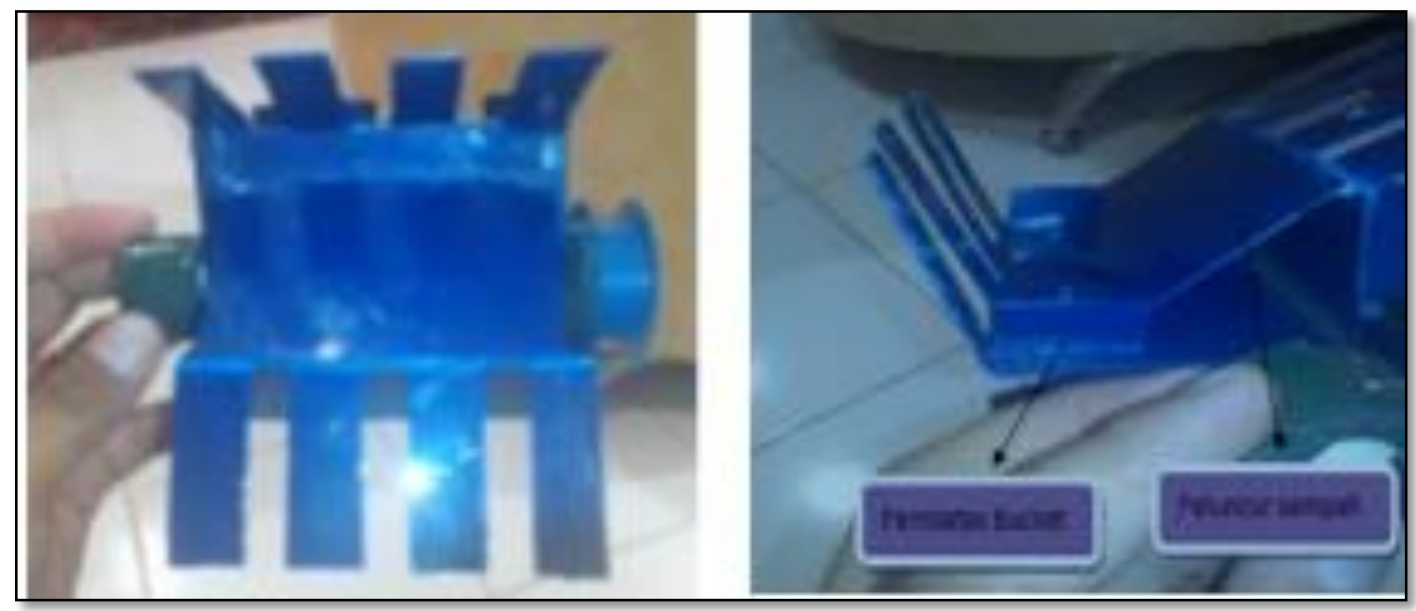

Gambar 3. Bucket dengan 4 lengan.

3. Penyaring sampah berbentuk bucket conveyor [7].

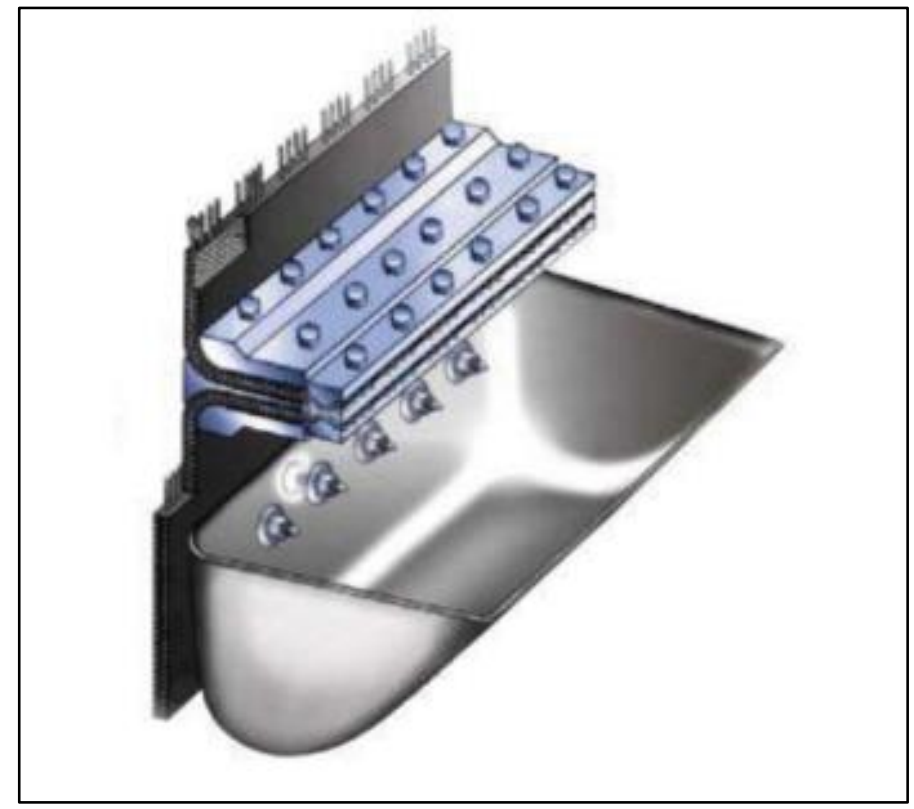

Gambar 4. Bucket.

4. Bentuk Penyaring Sampah yang dipilih.

JTTM : Jurnal Terapan Teknik Mesin is licensed under a Creative Commons AttributionNonCommercial 4.0 International License.

Perancangan Bentuk Penyaring Sampah Pada Alat Penyaring Sampah Sungai - Besse Titing Karmiati, Ressy Noor Rafiq 
Jurnal Terapan Teknik Mesin, Vol. 1, No. I, April 2020, 1 - 11

Dari beberapa bentuk penyaring diatas dipilih keunggulan dari masing-masing bentuk tersebut sehingga diperoleh bentuk penyaring sebagai berikut:

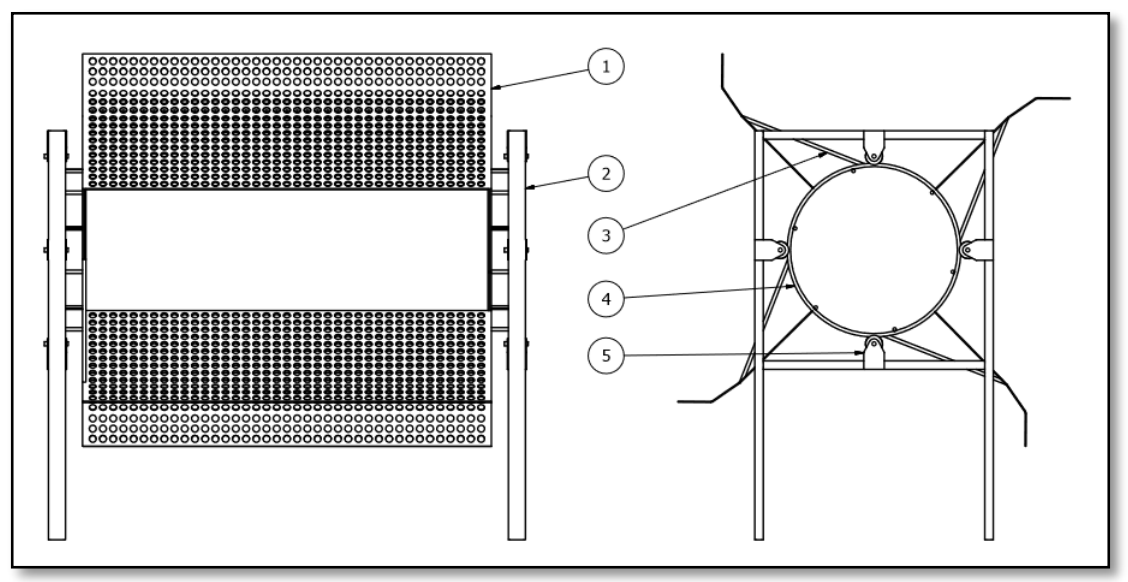

Keterangan :

Gambar 5. Bentuk penyaringan sampah

1. Saringan \& dudukan penyaring.

2. Penyangga saringan.

3. Rel penyaring.

4. Roda rel.

3 Hasil dan Pembahasan

3.1 Perancangan konsep bentuk penyaring sampah.

1. Mekanisme alat penyaring sampah.

Alat penyaring sampah sungai ini bertujuan untuk menyaring sampah yang ikut pada aliran sungai [8]. Alat penyaring sampah ini berbentuk kincir 4 lengan terbuat dari plat berlubang yang berputar searah jarum jam, dimana setiap lengan berkapasitas $7 \mathrm{~kg} /$ putaran. Setelah sampah tersaring maka sampah akan ikut putaran kincir dan jatuh pada belt conveyor, belt conveyor akan membawa sampah ke pinggir sungai. Kincir ini digerakkan oleh sebuah turbin yang dihubungkan dengan roda gigi dan pulley. Turbin yang digunakan adalah turbin cross flow dengan menggunakan energi potensial air.

2. Dimensi alat penyaring sampah, dengan menentukan beberapa estimasi dari komponen yaitu:

- Estimasi beban kincir.

Untuk beban kincir diperoleh dari bahan plat alminium berlubang dengan massa jenis $(\rho)$ $2700 \mathrm{~kg} / \mathrm{m}^{3}$, sesuai dengan bentuk kincir seperti gambar 6 diperoleh data sebagai berikut:

- Menghitung volume plat berlubang diperoleh:

JTTM : Jurnal Terapan Teknik Mesin is licensed under a Creative Commons AttributionNonCommercial 4.0 International License.

Perancangan Bentuk Penyaring Sampah Pada Alat Penyaring Sampah Sungai - Besse Titing Karmiati, Ressy Noor Rafiq 
Jurnal Terapan Teknik Mesin, Vol. 1, No. I, April 2020, 1-11

a. Luas kotor $(\mathrm{Ag})$ : Panjang $x$ Lebar.

b. Luas dengan lubang $(A n): A g-(d \times L)$

c. Volume (V): An x Tebal

- Berat lengan

- Lengan utama
a. Panjang
b. Lebar
$: 1.2 \mathrm{~m}$
c. Tebal
$: 0.3 \mathrm{~m}$
$: 0.0003 \mathrm{~m}$.

Luas $\operatorname{kotor}(\mathrm{Ag})=1,2 \times 0,3=0,36 \mathrm{~m}^{2}$

Luas dengan lubang $(A n)=0,36-(0,02 \times 0,3)=0,0354 m^{2}$

volume $(V)=0,0354 \times 0,003=0,001062 \mathrm{~m}^{2}$

berat $(m)=\rho x V=2700 \times 0,001062=2.87 \mathrm{~kg}$

- Lengan miring:
a. Panjang: $1.2 \mathrm{~m}$
b. Lebar : $0.1 \mathrm{~m}$
c. Tebal : :0,003 m

Luas kotor $(\mathrm{Ag}) \quad=1,2 \times 0,1=0,12 \mathrm{~m}^{2}$

Luas dengan lubang $(A n)=0,12-(0,02 \times 0,1)=0,118 m^{2}$

volume $(V) \quad=0,118 \times 0,003=0,000354 \mathrm{~m}^{2}$

berat $(\mathrm{m}) \quad=\rho x V=2700 \times 0,000354=0,955 \mathrm{~kg}$

- Lengan ujung:
a. Panjang $: 1.2 \mathrm{~m}$
b. Lebar : $0.2 \mathrm{~m}$
c. Tebal : 0,003 m

Luas kotor $(\mathrm{Ag})=1,2 \times 0,2=0,24 \mathrm{~m}^{2}$

Luas dengan lubang $(A n)=0,24-(0,02 \times 0,2)=0,236 m^{2}$

volume $(V)=0,236 \times 0,003=0,000708 \mathrm{~m}^{2}$

berat $(m)=\rho x V=2700 \times 0,000708=1,911 \mathrm{~kg}$

Total berat lengan $=2.87+0,955+1,911=5,736 \mathrm{~kg}$

- Beban lengan total:

1 lengan penyaring berisi sampah $=5,736+7=12,736 \mathrm{~kg}$.

3 Lengan penyaring kosong $\quad=5,736 \times 3=17,208 \mathrm{~kg}$.

JTTM : Jurnal Terapan Teknik Mesin is licensed under a Creative Commons AtributionNonCommercial 4.0 International License.

Perancangan Bentuk Penyaring Sampah Pada Alat Penyaring Sampah Sungai - Besse Titing Karmiati, Ressy Noor Rafiq 
Jurnal Terapan Teknik Mesin, Vol. 1, No. I, April 2020, 1 - 11

Rangka lengan

Total beban

$$
\begin{aligned}
& =1 \cdot 00 \mathrm{~kg} . \\
& =30,944 \mathrm{~kg} .
\end{aligned}
$$

$F=$ massa $\times$ gravitasi

$F=30,944 \times 9,8=303,25 \mathrm{~N}$

- Estimasi waktu pengangkatan lengan penyaring dari permukaan air ke atas conveyor $t=3$ detik.

- Estimasi ketinggian permukaan air ke belt conveyor ke belt conveyor 1,5 $\mathrm{m}$.

- Kebutuhan daya $=\frac{(F \times s)}{t}=\frac{(303,25 \times 1,5)}{3}$

$$
=151.62 \text { Watt. }
$$

- Detail gambar Penyaring

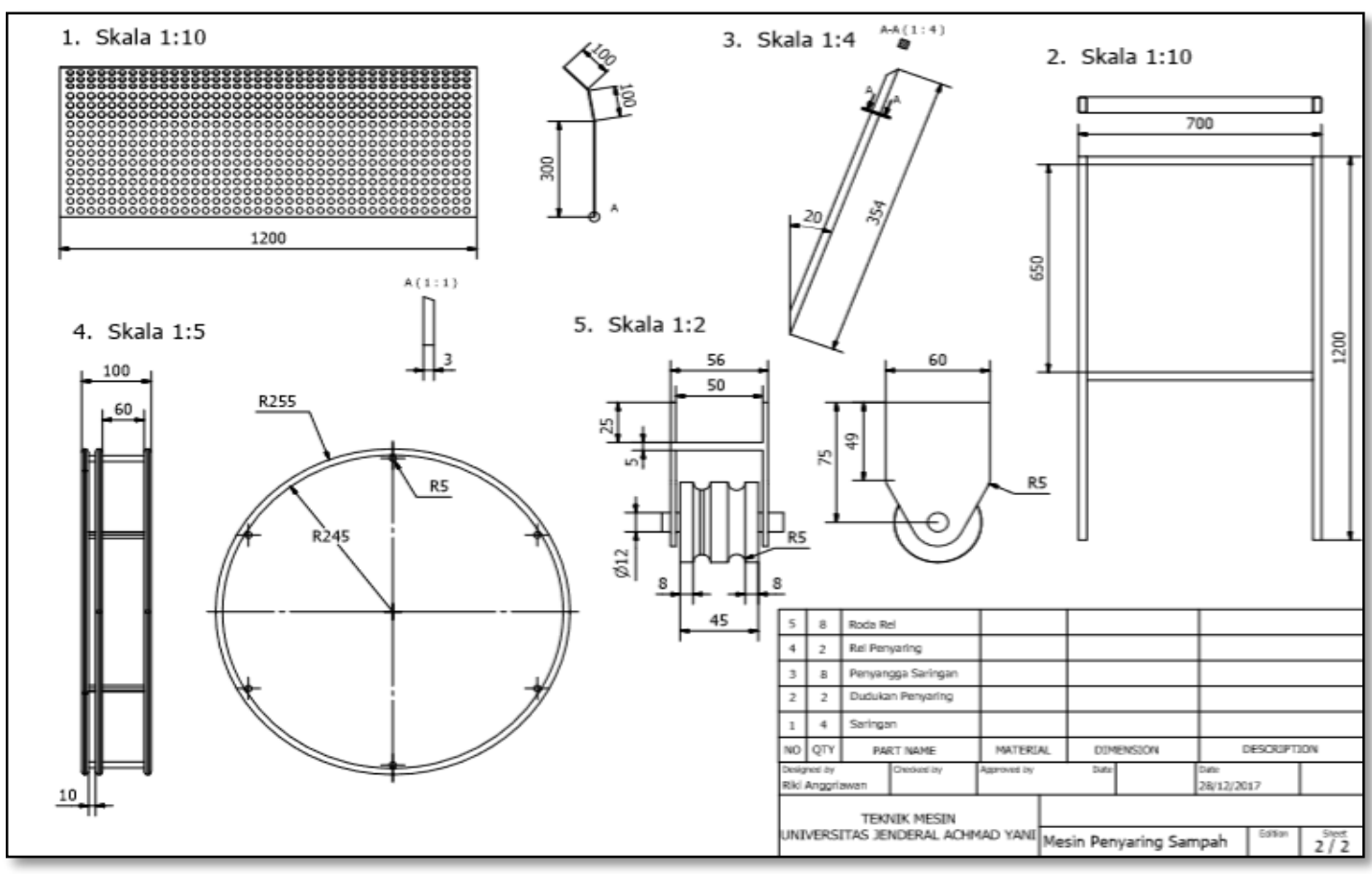

Gambar 6. Penyaring sampah.

JTTM : Jurnal Terapan Teknik Mesin is licensed under a Creative Commons AttributionNonCommercial 4.0 International License.

Perancangan Bentuk Penyaring Sampah Pada Alat Penyaring Sampah Sungai - Besse Titing Karmiati, Ressy Noor Rafiq 


\section{$\overline{J T T M}$}

Jurnal Terapan Teknik Mesin, Vol. 1, No. I, April 2020, 1 - 11

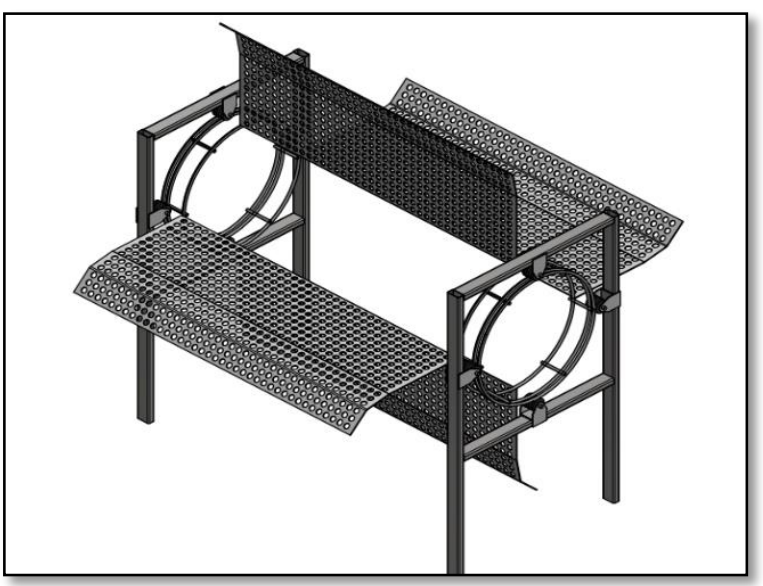

Gambar 7. Rancangan bentuk penyaring sampah

\subsection{Perencanaan Turbin Cross Flow.}

Diketahui dari hasil pengamatan debit aliran sungai pada lokasi 3 di sungai Cidurian adalah $2.685 \mathrm{~m}^{3} / \mathrm{s}$, dengan head awal $0.71 \mathrm{~m}$. dengan nilai debit dan head tersebut pada lokasi ini akan dibuat bendungan untuk mendapatkan head yang diinginkan atau direncanakan. Dengan nilai tersebut direncanakan akan digunakan turbin air type cross-flow [9] yang dapat digunakan pada aliran low head water flow, sebagaimana ditunjukan pada gambar 8:

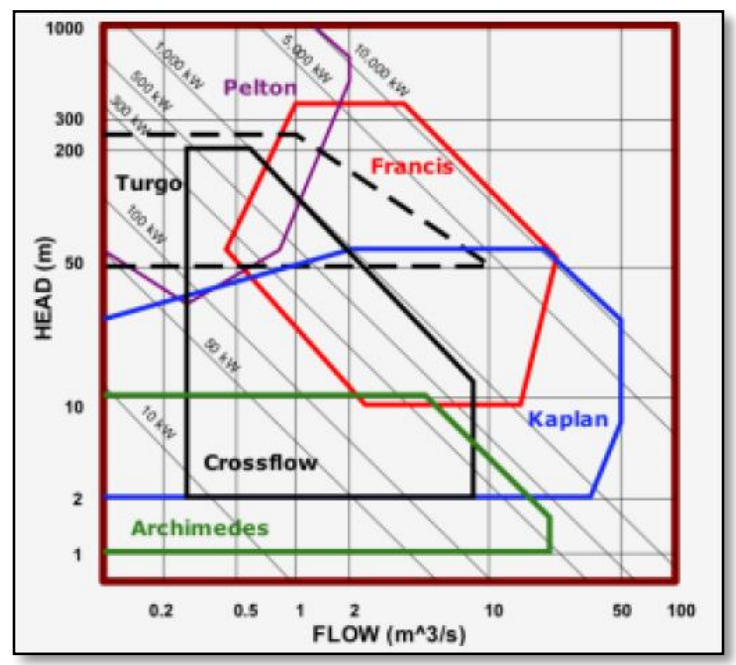

Gambar 8. Perencanaan turbin sesuai debit dan head.

JTTM : Jurnal Terapan Teknik Mesin is licensed under a Creative Commons AttributionNonCommercial 4.0 International License.

Perancangan Bentuk Penyaring Sampah Pada Alat Penyaring Sampah Sungai - Besse Titing Karmiati, Ressy Noor Rafiq 
Jurnal Terapan Teknik Mesin, Vol. 1, No. I, April 2020, 1-11

Untuk menyalurkan air sungai sebagai sumber penggerak mula turbin digunakan pipa pesat (penstock) dengan diameter $0.3048 \mathrm{~m}$ (12 inch).

Laju aliran air dari bendungan yang melalui pipa pesat dengan luas permukaan pipa,

$$
A=\frac{\pi}{4} D^{2}=\frac{3.14}{4} 0.3048^{2}=0.0729 \mathrm{~m}^{2}
$$

Maka diperoleh, $Q=A \sqrt{2 g h}=0.0729 \times \sqrt{2 \times 9.8 \times 1.5}=0.395433 \mathrm{~m}^{3} / \mathrm{s}$

Dari perhitungan debit maka diperoleh daya hidrolis air adalah:

$$
\begin{gathered}
W H P=\rho \times g \times H \times Q \\
W H P=999.7 \times 9.8 \times 1.5 \times 0.395433=5811.126 \text { Watt }
\end{gathered}
$$

Efisiensi turbin $50 \%$ sampai dengan $75 \%$

$$
\begin{gathered}
P_{\text {Turbin }}=\rho \times g \times H \times Q \times \eta \\
P_{\text {Turbin }}=999.7 \times 9.8 \times 1.5 \times 0.395433 \times 0.5=2905.563 \mathrm{Watt}
\end{gathered}
$$

Daya rencana yang dihasilkan turbin adalah 2905.563 Watt atau $2.9 \mathrm{kWatt}$.

4. SIMPULAN

Alat penyaring sampah ini berbentuk kincir 4 lengan terbuat dari plat berlubang yang berputar searah jarum jam, setiap lengan berkapasitas $7 \mathrm{~kg} /$ putaran dengan kebutuhan daya penyaring adalah 151,62 Watt dengan menggunakan turbin cross flow sebagai penggerak dengan daya rencana $2,9 \mathrm{~kW}$.

\section{UCAPAN TERIMAKASIH}

Penulis mengucapkan terima kasih atas LPPM UNJANI, dan jurusan Teknik mesin UNJANI atas dukungan pada penelitian ini untuk keikutsertaan dalam kegiatan ilmiah ini.

\section{DAFTAR PUSTAKA}

[1] H. S. Naryanto, P. Prihartanto, and D. Ganesha, "Kajian Kualitas Air Tanah dan Sungai pada Kawasan Rawan Banjir di Kabupaten Serang Kaitannya dengan Penyediaan Air Bersih," J. Teknol. Lingkung., vol. 20, no. 1, p. 45, 2019.

[2] "RIVER PLASTIC."

[3] H. Judul and A. S. Budi, "HALAMAN JUDUL Disusun oleh: ALFIYANSYAH SETIA BUDI NIM. I 0108053," 2013.

[4] H. Judul and B. Gunawan, "Floating Solid Waste Lifter By Double Hydraulic Wheel," 2013.

[5] P. T. Lingkungan and K. Puspiptek, "Prospek Pemanfaatan Penyaring Sampah Sungai

JTTM : Jurnal Terapan Teknik Mesin is licensed under a Creative Commons AttributionNonCommercial 4.0 International License.

Perancangan Bentuk Penyaring Sampah Pada Alat Penyaring Sampah Sungai - Besse Titing Karmiati, Ressy Noor Rafiq 
Jurnal Terapan Teknik Mesin, Vol. 1, No. I, April 2020, 1-11

dalam Implementasi Imbal Jasa Lingkungan di Daerah Aliran Sungai Ciliwung Segmen 2 Kota Bogor Prospects of Solid Waste River Filters Utilization in the Implementation of Payments for Environmental Services on th," vol. 18, no. 1, pp. 37-44, 2017.

[6] D. Pengembangan, Proses Pengolahan Sampah Organik dengan Black Soldier Fly ( $B S F)$. .

[7] S. Arief and A. Yusranaminy, "MAN - 054 Proceeding Seminar Nasional Tahunan Teknik Mesin XI (SNTTM XI) \& Thermofluid IV Universitas Gadjah Mada (UGM), Yogyakarta, 16-17 Oktober 2012," no. Snttm Xi, pp. 16-17, 2012.

[8] B. Vasanthakumar, M. Venkatesh, R. Vijayarakshana, and P. Preethi, "PROJECT KUMBHKARAN," vol. 118, no. 20, pp. 3399-3407, 2020.

[9] R. J. Cavagnaro and B. Polagye, "Stall Dynamics of a Cross-Flow Turbine," no. 4.

JTTM : Jurnal Terapan Teknik Mesin is licensed under a Creative Commons AttributionNonCommercial 4.0 International License.

Perancangan Bentuk Penyaring Sampah Pada Alat Penyaring Sampah Sungai - Besse Titing Karmiati, Ressy Noor Rafiq 